\title{
Development and characterization of active film with omega-3 as a proposal for enrichment of butter
}

\author{
Jackline Freitas Brilhante de SÃO JOSÉ ${ }^{1 \star}$, Hiasmyne Silva MEDEIROS², Fernanda Cristina Esteves de OLIVEIRA², \\ Allan Robledo FIALHO E MORAES 4 , Daniela da Silva OLIVEIRA ${ }^{5}$, Éber Antonio Alves Medeiros², \\ Nilda de Fátima Ferreira SOARES ${ }^{2}$
}

\begin{abstract}
Active food packaging aims to interact with food in order to improve nutritional, sensory, physicochemical or microbiological properties of the food products. The aim of this work was to development and characterization of active film with omega-3 and flavored with oregano essential oil for butter. It was produced three films: control (T1), active films added with $25 \%$ of $\omega-3$ fatty acid and 5\% of oregano essential oil (T2) and active film added with $40 \%$ fatty acid $\omega-3$ and $5 \%$ essential oil of oregano (T3). Physical, mechanical and structural films properties were evaluated. The addition of fish oils and essential oregano did not change neither films color nor thickness in relation of control film. However, it reduced energy at break (J) and maximum compressive strength (MPa) of the active films. On the other hand, it increased elongation at break $(\mathrm{mm})$ of active films compared to control. WVP of control film was higher $(\mathrm{p}<0.05)$ to active films. In structural characterization, active films presented difference between the size of the oil droplets. It has been observed that the films produced have good mechanical, physical and structural properties. Further studies should be conducted for sensory evaluation, nutritional aspects and storage stability.
\end{abstract}

Keywords: active packaging; essential oil; fish oil; quality.

Practical Application: Adding omega on film to increase nutritional quality.

\section{Introduction}

Consumers worldwide have begun to focus not only on the safety of food products, but also on their quality and diversity. To conserve product quality, it is essential to select the correct packaging materials and technologies. Recent industry trends include the development of packaging materials that interact with the food and have an active role in the preservation of the food quality. One option, which has been widely studied, is active packaging that is developed by the incorporation of the active substance in the packaging material (Pavli et al., 2018).

Consumption of an adequate proportion of fatty acids $\omega-3$ and $\omega-6$ is directly associated with a decreased risk of chronic diseases (Brostow et al., 2011; Wang et al., 2012; Lopes \& Reis, 2014). This has encouraged many studies that evaluated the effect of different proportions of these two types of lipids in the diet in order to unsderstand the best relation to get beneficial health effects (Heller et al., 2007; Wang et al., 2009). A substantial increase in the daily intake of polyunsaturated fatty acids of the $\omega-3$ through food source such as fish, are required to meet the recommendations (Lionetti et al., 2014; Lopes \& Reis, 2014).

Due to some limitations, especially geographic and financial, consumption derived from fish by most of the population is low. In trade there are different fortified products such as bread, milk, among others, with $\omega-3$ fatty acids. However, production of such food products is a difficult task, since it requires special technology to prevent food present flavor/odors and also prevent the oxidation of fatty acids (Gökmen et al., 2011; Ganesan et al., 2014). An alternative for enrichment with $\omega-3$ would be in butter.

Butter is defined as "fat product is obtained exclusively by banging and mixing, with or without organic modification only pasteurized cream derived from cow's milk by technologically suitable promise. The fat content of butter should be composed exclusively of milk fat" (Brasil, 1996). According to the Organization for Economic Co-operation and Development, butter consumption in 2017 in Brazil was $0.62 \mathrm{~kg} /$ person/year (Organization for Economic Co-operation and Development, 2018), with estimated increase to 2025 (0.63 kg/person/year) and therefore can be a food product option for incorporation of $\omega-3$ fatty acids.

Films and coatings should be designed to meet a number of requirements such as mechanical, optical and appropriate barrier (Sánchez-González et al., 2010; Lopes et al., 2014). The incorporation of substances into films not only offers the opportunity for the film to interact with the food but can also modify the film properties (Moraes et al., 2007). Pavli et al. (2018)

${ }^{1}$ Departamento de Educação Integrada em Saúde, Centro de Ciências da Saúde, Universidade Federal do Espírito Santo, Vitória, ES, Brasil

${ }^{2}$ Departmento de Tecnologia de Alimentos, Universidade Federal de Viçosa, Viçosa, MG, Brasil

${ }^{3}$ Departamento de Engenharia de Alimentos, Universidade Federal de São João del-Rei, Sete Lagoas, MG, Brasil

${ }^{4}$ Instituto de Ciências Agrárias, Universidade Federal de Viçosa, Campus Rio Paranaíba, Rio Paranaíba, MG, Brasil

${ }^{5}$ Departamento de Farmácia e Nutrição, Universidade Federal do Espírito Santo, Alegre, ES, Brasil

${ }^{*}$ Corresponding author: jackline.jose@ufes.br 
highlighted the migration of the active compounds for food packaging contributes to consumer safety, since these compounds are not directly added to foods. Changes in film properties such as reduced permeability to water vapor (PWV), decreased tensile strength (RT) and increased elongation at break caused by incorporation of active substances (Kechichian et al., 2010; Sánchez-González et al., 2010).

The present work aimed to develop and characterize active packaging incorporated with omega 3 and flavored with oregano essential oil for enrichment of butter.

\section{Material and methods}

\subsection{Materials}

For mounting and conducting the experiments, were used cellulose acetate (CA), donated by the company Rhodia ${ }^{\circledR}$, PA acetone $\left(\operatorname{Vetec}^{\circledR}\right.$, Rio de Janeiro, Brazil), fish oil polyunsaturated $\omega-3$ fatty acids donated by the company Catarinense Pharma ${ }^{\circledR}$ (Joinville, Brazil) and was acquired essential oil of oregano (Ferquima $^{\circledR}$, Vargem Grande Paulista, Brazil).

\section{Preparation of films}

The films were prepared using the casting method described by Soares (1998) with some modifications. Preliminary tests were performed to verify the percentage of cellulose acetate, $\omega-3$ and essential oil capable of formation of film.

Three films were prepared: control film, without adding any active compound (T1), film with addition of $25 \% \omega-3$ and $5 \%$ of essential oregano oil (T2) and film with addition of $40 \% \omega-3$ and 5\% essential oregano oil (T3). All compounds incorporated into the package are suitable for food contact. The films were exposed to UV light $(254 \mathrm{~nm})$ for two minutes for sterilization before using as primary packaging for butter.

\subsection{Evaluation of physical, mechanical and structural films}

\section{Film thickness}

Film thickness was determined using a manual micrometer (Mitutoyo $0.01 \mathrm{~mm}$ (Mitutoyo Co.,Musashi Shinden,Tokyo, Japan)). The final thickness was determined by the arithmeric mean of 3 aleatory measurements of each sample.

\section{Color}

Color measurements were determined using the Colour Quest XE colorimeter (Huber Lab,Tampa, FL) and CIELab system with a D65 source illuminant and observation angle of $10^{\circ}$. The following properties were determined chromaticity $\left(C^{\star}\right)$ and global color difference $\left(\Delta E^{*}\right)$ using Equations 1 and 2:

$\mathrm{C}^{*}=\left(\mathrm{a}^{*^{2}+\mathrm{b}^{* 2}}\right)^{1 / 2}$

Where $a^{*}$ is the intensity of red/green and $b^{*}$ the intensity of yellow/blue

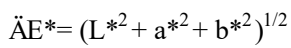

Where $\mathrm{L}^{*}$ is the lightness.

\section{Mechanical properties}

Films were analyzed for penetration resistance and the following properties were determined: tenacity $(\mathrm{J})$, tensile strength (MPa) and elongation at break (\%) using a universal testing equipment (Instron model 3367, Norwood, Mass., U.S.A.), with a $1 \mathrm{kN}$ load cell, cross head speed of $25 \mathrm{~mm} \cdot \mathrm{min}^{-1}$. Total of 9 samples of each film $(76 \times 76 \mathrm{~mm})$ were analyzed (American Society Standard Testing and Materials, 2008).

\section{Water Vapor Permeability (WVP)}

WVP was determined according to ASTM method E96-00 (American Society Standard Testing and Materials, 2000) with some modifications. Each film was sealed in the circular opening of a permeation cell with an $80 \mathrm{~mm}$ internal diameter to ensure that humidity migration occurred only through the film. The interior of the cell was filled with anhydrous calcium chloride $(\mathrm{CaCl} 2)$. The permeation cell was then placed in a controlled temperature and humidity chamber maintained at $75 \%$ relative humidity (RH) and $25^{\circ} \mathrm{C}$ to maintain a $75 \% \mathrm{RH}$ gradient across the film so that water vapor permeation could be determined from the weight gain of the permeation cell.

The samples were weighed until a constant weight gain was reached and plotted in the time function. The slope of each line was calculated by linear regression $\left(\mathrm{r}^{2}>0.99\right)$ and the water vapor permeation ratio (WVPR, $\mathrm{g} \cdot \mathrm{s}^{-1} \cdot \mathrm{m}^{2}$ ) was calculated from the slope of the straight line divided by the exposed film area $\left(\mathrm{m}^{2}\right)$, as shown in Equation 3:

$\mathrm{WVPR}=\frac{\mathrm{m}}{\mathrm{t} \cdot \mathrm{A}}$

Where $\mathrm{m} / \mathrm{t}$ is the angular coefficient of the curve and $\mathrm{A}$ is the sample permeation ratio. The WVP $\left(\mathrm{g} \cdot \mathrm{Pa} \cdot \mathrm{s}^{-1} \cdot \mathrm{m}^{-1}\right)$ was then calculated as shown in Equation 4:

$$
\mathrm{WVP}=\frac{\mathrm{WVPR} \cdot \mathrm{st}}{\mathrm{sp}\left(\mathrm{RH}_{1}-\mathrm{RH}_{2}\right)}
$$

Where st is the mean sample thickness ( $\mathrm{m})$, sp is the water vapor permeability saturation pressure at the assay temperature $(\mathrm{Pa})$, $\mathrm{RH} 1$ is the relative humidity of the chamber and $\mathrm{RH} 2$ is the relative humidity in the interior of the permeation cell.

\section{Structural characterization}

Microscopic characteristics of the films were evaluated by scanning electronic microscopy (SEM). In the SEM analysis, pieces of films $\left(20 \times 50 \mathrm{~mm}^{2}\right)$ from each treatment were cut and fixed in a little support (stub). The samples were coated with a $20 \mathrm{~nm}$-thick gold layer inside a metallizer Balzers FDU010 (Bal-Tec, Balzers, Liechenstein) and were observed and photographed with scanning electronic microscope (LEO 1430 VP, Carl Zeiss, Cambridge, England).

\subsection{Statistical analysis}

The thickness, mechanical properties, color and WVP data of the films were subjected to an analysis of variance and the averages of the treatments were compared by the Tukey's test 
at $5 \%$ probability using SAS (Statistical Analysis System - SAS Institute Inc., North Carolina, USA), licenciated by Federal University Viçosa.

\section{Results and discussion}

\subsection{Evaluation of physics, mechanical and structural properties of the films}

\section{Film thickness}

The average films were not significantly different between treatments, and the value was $33.1 \pm 0.18 \mu \mathrm{m}$, which indicated a good control over the production process. Such control is very important because it determines the uniformity of the formed film, reproducibility of measurements and validity of the comparison between film (Stone \& Sidel, 1993).

\section{Color}

The addition of fish oils and essential oregano, the concentrations used did not change ( $p>0.05)$, in respect of the films, chromaticity $\left(\mathrm{C}^{\star}\right)$ and overall color difference $(\Delta \mathrm{E})$, with mean values of $2.10 \pm 1.77$ and $408 \pm 203.52$, respectively.

Non-interference by adding the oils on the colorimetric properties indicates that probably the film would not have a negative evaluation from consumers, with respect to the control film. The visual aspect is related to the color and transparency of films, attributes that influence acceptability of the consumer by the product.

\section{Mechanical properties}

For all the analyzed mechanical properties, the behavior was similar between treatments (Table 1), and the control differed $(\mathrm{p}<0.05)$ from the other two treatments, which did not differ $(\mathrm{p}>0.05)$.

The mechanical properties of films are associated with their behavior during handling and storage of food. The parameters analyzed in this are useful for specifying and evaluating the quality of these materials.

The addition of fish oils and essential oregano reduced energy at break $(\mathrm{J})$ and the maximum compressive strength $(\mathrm{MPa})$, and increased elongation at break $(\mathrm{mm})$ of active films compared to

Table 1. Means of mechanical properties and permeability to water vapor in control film and film with addition of $\omega-3$ and essential oregano oil.

\begin{tabular}{ccccc}
\hline Treatment $^{*}$ & $\begin{array}{c}\text { Energy of } \\
\text { rupture }(\mathrm{J})\end{array}$ & $\begin{array}{c}\text { Maximum } \\
\text { resistance to } \\
\text { compression } \\
(\mathrm{MPa})\end{array}$ & $\begin{array}{c}\text { Elongation at } \\
\text { break }(\mathrm{mm})\end{array}$ & $\begin{array}{c}\text { WVP } \\
(\mathrm{g} / \mathrm{s} . \mathrm{m} . P a)\end{array}$ \\
\hline T1 & $0.206^{\mathrm{a}}$ & $1.41^{\mathrm{a}}$ & $26.65^{\mathrm{a}}$ & $5.19^{\mathrm{a}}$ \\
T2 & $0.062^{\mathrm{b}}$ & $0.76^{\mathrm{b}}$ & $20.5^{\mathrm{b}}$ & $2.90^{\mathrm{b}}$ \\
T3 & $0.091^{\mathrm{b}}$ & $0.91^{\mathrm{b}}$ & $21.95^{\mathrm{b}}$ & $3.04^{\mathrm{b}}$
\end{tabular}

${ }^{*}$ Control film, without adding any active compound (T1), film with addition of $25 \% \omega-3$ and $5 \%$ of essential oregano oil (T2) and film with addition of $40 \% \omega-3$ and $5 \%$ essential oregano oil (T3). Means followed by the same letter, for the same column do not differ statistically $(\mathrm{p}>0.05)$. the control. These properties are very important to defining the mechanical characteristics of the films and are directly related to their chemical structures. Probably, fish oils and essential oregano interacted with cellulose acetate acting as plasticizers. Thus, a reduction of intermolecular interactions between the polymer chains of the cellulose acetate and thus increase its molecular mobility (Mchugh \& Krochta, 1994; Du et al., 2009).

Similar results were obtained by Rojas-Graü et al. (2007) who observed an increase in the percentage of stretch in alginate films and applesauce incorporated with OE oregano, cinnamon and lemongrass. According to these results, the small percentage control film elongation of the polymer matrix values may be due to the presence of cellulose acetate agglomerates and fish oil, which compared with those observed in the control films are much higher. The size of these clusters may have influenced the percentage elongation of the film with fish oil allowing them to be more flexible, as well as the presence of the essential oil of oregano in the polymer matrix, which caused a plasticizing effect on films.

Qin et al. (2015) evaluated tensile strength and elongation at break of an active chitosan film incorporated with montmorillonite and natural antioxidants extracted from pomegranate rind and observed that tensile strength and elongation at break of the films was affected by the addition of montmorillonite.

The incorporation of components is useful to promote the adequacy of properties for later application in food packaging.

\section{Water Vapor Permeability (WVP)}

The control film of WVP $(\mathrm{T} 1)$ was higher $(\mathrm{p}<0.05)$ to active films, and there was no statistical difference between those last two (T2 and T3). This is a positive result because one of the main useful properties of a food packaging is regularly to avoid or at least to reduce moisture transfer between the food and environment. Thus, WVP must be as low as possible (Qin et al., 2015).

The plasticizer effect of fish oils and oregano could, on principle, lead to an increase in WVP films of assets due to these plasticizing action on assets films. However, the hydrophobic nature of the oils means that there is less interaction with water, resulting in a reduction of WVP. Another factor that may have contributed to lower permeability is that the droplets of oil may have occupied part of the voids between the chains of cellulose acetate, hindering the permeation of water molecules of the active films, compared to the film control (Moura et al., 2014).

The film's moisture barrier is measured as the WVP and the factors that affect permeability films are of chemical and structural nature. WVP is related the application of films in different types of food and storage conditions (Azevedo et al., 2014).

\section{Structural characterization}

It is observed that the droplets of fish oils and oregano formed the dispersed phase while the continuous phase is formed by the polymeric matrix of the continuous cellulose acetate (Figure 1). 


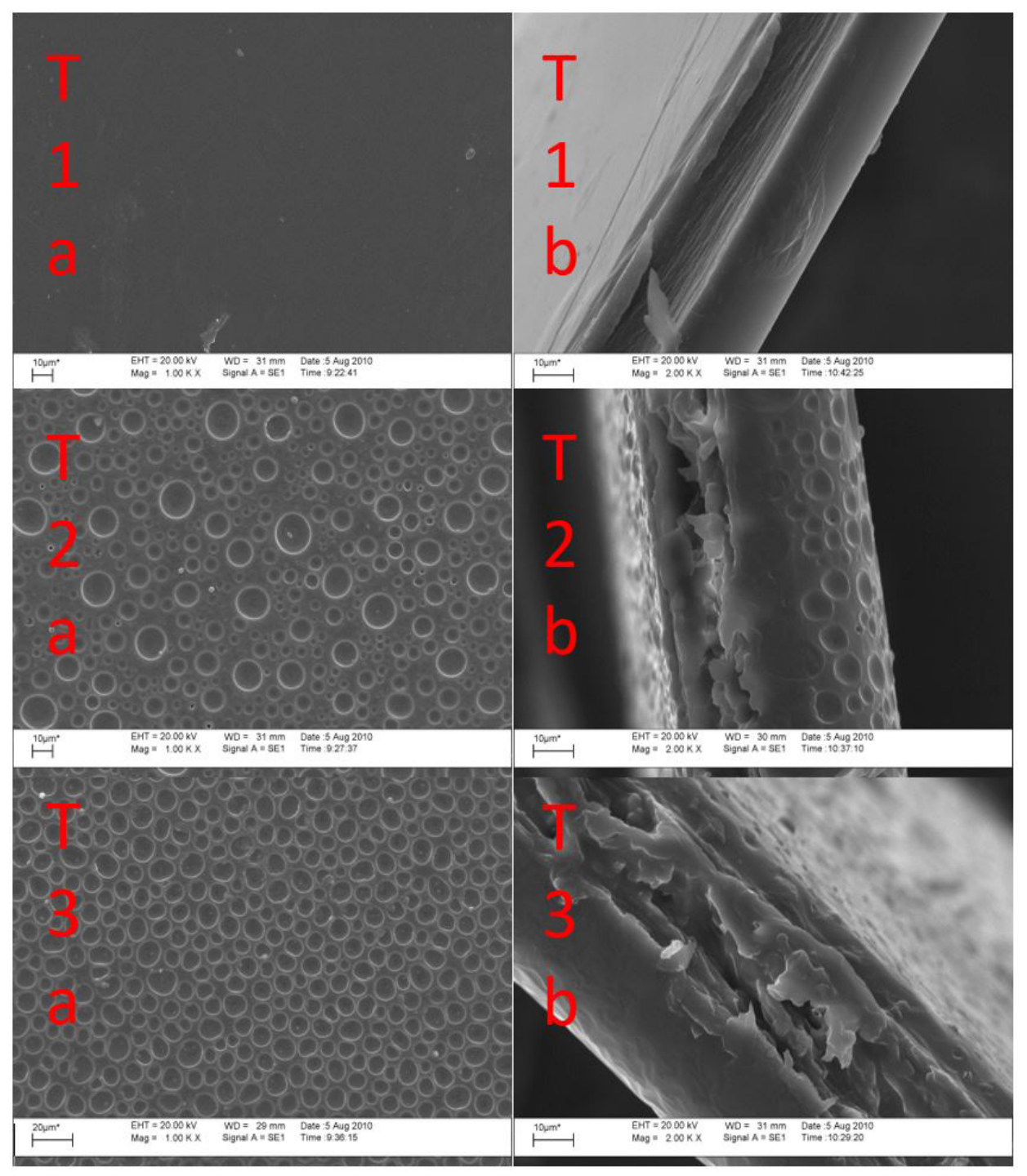

Figure 1. Photomicrographs of films obtained by SEM: control film - shallow (T1a), control film - fracture (T1b); active film with $25 \%$ of $\omega-3$ and 5\% oregano essential oil - shallow (T2a) and active film fracture (T2b); and active film with $40 \%$ of $\omega$ - 3 and $5 \%$ oregano essential oil shallow (T3a) and active film fracture (T3b).

As expected, the film control (T1) presented a homogenous structure. We observed that film T3 had better distribution of droplet size in comparison film T2. Probably due to the fact that those film presented higher amounts of $\omega-3$, since by reducing the size of droplets reduces the interfacial tension between the oil (apolar) and the chains of cellulose acetate (polar). Despite this difference between the size of the oil droplets observed in films, there was no significant difference between T2 and T3 in relation to physical, mechanical properties and permeability to water vapor of the active films.

Qin et al. (2015) performed analysis of the surface morphology of pure chitosan and observed a homogenous dispersion of the components in the sample of pure chitosan and in the chitosan-based composite films, montmorillonite particles were dispersed throughout the chitosan matrix, and a separation of chitosan matrix was observed.
This demonstrates that addition of different materials to the base polymer of the film can reduce the homogeneity in the distribution of the components. However, this change in the distribution of the components can confer characteristics that contribute to the film.

\section{Conclusion}

The addition of $\omega-3$ and oregano essential oil did not result in changes in color and thickness of the developed film compared to the control film. On the other hand, resulted in a reduction of the energy at break and maximum compressive strength and implied and increased elongation, as well as a reduction in the permeability to water vapor of the active films. In structural characterization, active films presented difference between the size of the oil droplets. It has been observed that the films produced have good mechanical, physical and structural 
properties. Mechanical properties reflect the ability of film to protect the integrity of foods. Further studies should be conducted for sensory evaluation, nutritional aspects and storage stability.

\section{References}

American Society Standard Testing and Materials - ASTM. (2000). Standart test method for water vapor transmission of materials. E 96-00. Philadelphia: ASTM.

American Society Standard Testing and Materials - ASTM. (2008). Standart test method for slow rate penetration resistance of flexible barrier films and laminates. F 1306. Philadelphia: ASTM.

Azevedo, V., Costa, A., Fukushima, K., \& Borges, S. (2014). Propriedades de barreira, mecânicas e ópticas de filmes de concentrado proteico de soro de leite. Revista do Instituto de Latícinios Cândido Tostes, 69(4), 237-247. http://dx.doi.org/10.14295/2238-6416.v69i4.307.

Brasil. Ministério da Agricultura do Abastecimento e da Reforma Agrária. (1996, Março 11). Regulamento Técnico de Identidade e Qualidade de Manteiga (Portaria no 146, de 07 de março de 1996). Diário Oficial [da] República Federativa do Brasil Retrieved from http://extranet.agricultura.gov.br/sislegis-consulta/consultarLegislacao. do? operacao $=$ visualizar $\&$ id $=1218$

Brostow, D. P., Odegaard, A., Koh, W.-P., Duval, S., Gross, M. D., Yuan, J.-M., \& Pereira, M. (2011). Omega-3 fatty acids and incident type 2 diabetes: the Singapore Chinese Health Study. The American Journal of Clinical Nutrition, 94(2), 520-526. http://dx.doi.org/10.3945/ ajcn.110.009357. PMid:21593505.

Du, W. X., Olsen, C. W., Avena-Bustillos, R. J., McHugh, T. H., Levin, C. E., \& Friedman, M. (2009). Effects of allspice, cinnamon, and clove bud essential oils in edible apple films on physical properties and antimicrobial activities. Journal of Food Science, 74(7), M372-M378. http://dx.doi.org/10.1111/j.1750-3841.2009.01282.x. PMid:19895483.

Ganesan, B., Brothersen, C., \& McMahon, D. J. (2014). Fortification of Foods with Omega-3 Polyunsaturated Fatty Acids. Critical Reviews in Food Science and Nutrition, 54(1), 98-114. http://dx.doi.org/10.1 080/10408398.2011.578221. PMid:24188235.

Gökmen, V., Mogol, B. A., Lumaga, R. B., Fogliano, V., Kaplun, Z., \& Shimoni, E. (2011). Development of functional bread containing nanoencapsulated omega-3 fatty acids. Journal of Food Engineering, 105(4), 585-591. http://dx.doi.org/10.1016/j.jfoodeng.2011.03.021.

Heller, A. R., Stengel, S., Stehr, S. N., Gama de Abreu, M., Koch, R., \& Koch, T. (2007). Impact of the ratio of intravenous omega-3 vs. omega- 6 polyunsaturated fatty acids in postoperative and in septic patients-A post hoc database analysis. e-SPEN, the European e-Journal of Clinical Nutrition and Metabolism, 2(5), e91-e96. http:// dx.doi.org/10.1016/j.eclnm.2007.07.002.

Kechichian, V., Ditchfield, C., Veiga-Santos, P., \& Tadini, C. C. (2010). Natural antimicrobial ingredients incorporated in biodegradable films based on cassava starch. Lebensmittel-Wissenschaft + Technologie, 43(7), 1088-1094. http://dx.doi.org/10.1016/j.lwt.2010.02.014.

Lionetti, L., Mollica, M. P., Donizzetti, I., Gifuni, G., Sica, R., Pignalosa, A., Cavaliere, G., Gaita, M., De Filippo, C., Zorzano, A., \& Putti, R. (2014). High-Lard and High-Fish-Oil Diets Differ in Their Effects on Function and Dynamic Behaviour of Rat Hepatic Mitochondria. PLoS One, 9(3), e92753. http://dx.doi.org/10.1371/journal.pone.0092753. PMid:24663492.

Lopes, A. C. N. S., \& Reis, L. B. S. M. (2014). Influência dos ácidos graxos poliinsaturados ômega-3 no diabetes mellitus. Ciência \& Saúde, 25(2), 141-148.
Lopes, F. A., Soares, N., Lopes, C. C. P., \& Silva, W. A. (2014). Desenvolvimento e caracterização de filmes de base celulósica incorporados com aldeído cinâmico. Brazilian Journal of Food Technology, 17(1), 33-40. http://dx.doi.org/10.1590/bjft.2014.006.

Mchugh, T. H., \& Krochta, J. M. (1994). Sorbitol-vs glycerol-plasticized whey protein edible films: integrated oxygen permeability ad tensile property evaluation. Journal of Agricultural and Food Chemistry, 42(4), 841-845. http://dx.doi.org/10.1021/jf00040a001.

Moraes, A. R. F., Gouveia, L. E. R., Soares, N., Santos, M. M. S., \& Gonçalves, M. P. J. C. (2007). Desenvolvimento e avaliação de filme antimicrobiano na conservação de manteiga. Food Science and Technology, 27(Suppl.), 33-36. http://dx.doi.org/10.1590/S010120612007000500006.

Moura, M. R., Aouada, F. A., Souza, J. R., \& Mattoso, L. H. C. (2014). Preparação de novos nanobiocompósitos comestíveis ativos contendo nanoemulsão de canela e pectina. Polímeros, 24(4), 486-490. http:// dx.doi.org/10.1590/0104-1428.1508.

Organization for Economic Co-operation and Development - OECD. (2018). OECD-FAO Agricultural Outlook 2016-2025. DAIRY - OECDFAO Agricultural Outlook 2016-2025. Brazil. Retrieved from http:// stats.oecd.org/index.aspx?datasetcode=high_aglink_2016.

Pavli, F., Tassou, C., Nychas, G. J. E., \& Chorianopoulos, N. (2018). Probiotic incorporation in edible films and coatings: Bioactive solution for functional foods. International Journal of Molecular Sciences, 19(1), 150. http://dx.doi.org/10.3390/ijms19010150. PMid:29300362.

Qin, Y.-Y., Zhang, Z.-H., Li, L., Yuan, M.-L., Fan, J., \& Zhao, T.-R. (2015). Physio-mechanical properties of an active chitosan film incorporated with montmorillonite and natural antioxidants extracted from pomegranate rind. Journal of Food Science and Technology, 52(3), 1471-1479. http://dx.doi.org/10.1007/s13197-013-1137-1. PMid:25745215.

Rojas-Graü, M. A., Avena-Bustillos, R. J., Olsen, C., Friedman, M., Henika, P. R., Martín-Belloso, O., Pan, Z., \& McHugh, T. H. (2007). Effects of plant essential oils and oil compounds on mechanical, barrier and antimicrobial properties of alginate-apple puree edible films. Journal of Food Engineering, 81(3), 634-641. http://dx.doi. org/10.1016/j.jfoodeng.2007.01.007.

Sánchez-González, L., Cháfer, M., Chiralt, A., \& González-Martínez, C. (2010). Physical properties of edible chitosan films containing bergamot essential oil and their inhibitory action on Penicillium italicum. Carbohydrate Polymers, 82(2), 277-283. http://dx.doi. org/10.1016/j.carbpol.2010.04.047.

Soares, N. F. F. (1998). Bitterness reduction in citrus juice through naringinase immobilized into polymer film (Ph.D. diss). Cornell University, Ithaca.

Stone, H., \& Sidel, J. L. (1993). Sensory Evaluation Practices. San Diego: Academic Press.

Wang, S., Wu, D., Matthan, N. R., Lamon-Fava, S., Lecker, J. L., \& Lichtenstein, A. H. (2009). Reduction in dietary omega-6 polyunsaturated fatty acids: Eicosapentaenoic acid plus docosahexaenoic acid ratio minimizes atherosclerotic lesion formation and inflammatory response in the LDL receptor null mouse. Atherosclerosis, 204(1), 147-155. http://dx.doi.org/10.1016/j.atherosclerosis.2008.08.024. PMid:18842266.

Wang, S.-P., Chen, Y.-H., \& Li, H. (2012). Association between the levels of polyunsaturated fatty acids and blood lipids in healthy individuals. Experimental and Therapeutic Medicine, 4(6), 1107-1111. http:// dx.doi.org/10.3892/etm.2012.724. PMid:23226783. 